\title{
PHYTOCHEMICAL CONSTITUENTS OF PENCIL TREE (EUPHORBIA TIRUCALLI L.) AS ANTIFUNGAL AGENT AGAINST MANGO ANTHRACNOSE DISEASE
}

\author{
KHAN, B. ${ }^{1}-$ JABEEN, K. ${ }^{1 *}-$ KANWAL, Q. ${ }^{2}-$ IQBAL, $S .{ }^{1}$ \\ ${ }^{I}$ Department of Botany, Lahore College for Women University, Lahore, Punjab 54000, Pakistan \\ ${ }^{2}$ Department of Chemistry, University of Lahore, Raiwind Road Campus, Lahore, Punjab, \\ Pakistan \\ *Corresponding author \\ e-mail: Khajista_1@hotmail.com; phone: +92-334-993-1766
}

(Received $25^{\text {th }}$ Dec 2020; accepted $14^{\text {th }}$ May 2021)

\begin{abstract}
The current study aimed to examine the Euphorbia tirucalli L. (pencil tree) in vitro antifungal activity against Colletotrichum gloeosporioides Penz. All the tested extract concentrations (1-3\%) showed a significant decrease in the test fungus growth. However, $3 \%$ conc. exhibited the highest reduction in $C$. gloeosporioides biomass at 77\%. Methanolic extract of E. tirucalli was examined through phytochemical analysis and determining flavonoids, saponins, terpenoids, tannins and alkaloids. The antioxidant activity of E. tirucalli was also tested using radical scavenging assay (DPPH), and $81 \%$ activity was observed at $200 \mu \mathrm{L}$ conc. of methanol extract. Further solvent partitioning bioassay was employed to check the efficacy of the various isolated fractions viz. ethyl acetate, chloroform, $n$-hexane and $n$-butanol of the test plant against $C$. gloeosporioides. The bioassay results depicted that $0.5 \%$ and $1 \%$ concentration of the chloroform fraction of E. tirucalli caused the highest decline in the growth of $C$. gloeosporioides, i.e. $90 \%$ and $95 \%$. This most effective extract was examined via GC-MS (gas chromatography-mass spectrometry). The major constituents identified were 9, 12-octadecadienoic acid (Z, Z)-, $n$-hexadecanoic acid, dodecanoic acid, tetradecanoic acid and phytol. Results suggest that active compounds detected by GC-MS analysis of E. tirucalli might be responsible for its antifungal potential.
\end{abstract}

Keywords: antifungal bioassay, DPPH, flavonoids, phytochemicals, solvent partitioning bioassay

\section{Introduction}

Mangifera indica L., commonly known as mango, is cultivated in the tropics and subtropical parts of the world (Sauco, 2017). It is the most popular commercially produced fruit crop. Pakistan, India, Brazil, Peru, Mexico, and the Philippines are the chief distributors of mango worldwide (Memon, 2016; Huang et al., 2018). Mango is an excellent source of fibre and powerful biochemicals such as carotenoids, provitamin A, vitamin $\mathrm{C}$ and phenolics. Owing to the availability of ample nutrients and impedance health benefits, fruits and vegetables have been of great importance in preventing various chronic diseases (Slavin and Lloyd, 2012; Schulze-Kayserset al., 2015; Shah et al., 2019).

Colletotrichum gloeosporioides is one of the main plant pathogenic fungus responsible for anthracnose disease in mango. This fungus favours mild, humid environments for the constant and effective spread of anthracnose disease (Farr et al., 2006; Dean et al.,2012). Anthracnose disease dangerously deteriorates the mango crop, blooms with clear, deep, dusky brown to blackish spots on fruit before or after harvesting, and fruit may fall from trees prematurely (Pandey et al., 2012). At harvest, fruits that seem healthy may develop severe anthracnose symptoms once they ripen (Kenganalet al., 2010).

The successful approach against anthracnose disease is to employ post-harvest treatments with inorganic salts and hot-water dipping (Dessalegn et al., 2013). 
Various fungicides, such as copper hydroxide, azoxystrobin, mancozeb, prohloraz and copper sulfate products, are used to treat infection of $C$. gloeosporioides (Dirouet al., 2005; Sundravadanaet al., 2006). To improve resistance and development in the onset of disease, a lot of research has been conducted. However, the overproduction of precursors can overpower the disrupted biochemical pathway. Fungal cells can evolve mechanisms to prevent the fungicide from entering the cells and efficiently export the chemical out. The benzimidazole fungicides blocked the polymerization of tubulin and prevented the nuclear division of fungal cells. Simple natural mutations allowed for the creation of resistant fungi since the mode of action is so unique within the fungi. Therefore, resistance is very constant within the population and has developed due to the widespread use of benzimidazole fungicides (Pscheidt and Ocamb, 2018). Kumar et al. (2007) studied carbendazim (50 ppm), thiophanate-methyl (50 ppm), propiconazole $(25 \mathrm{ppm})$, and hexaconazole $(25 \mathrm{ppm})$ and two non-systemic fungicides, mancozeb (1000 ppm) and copper oxychloride (1000 ppm), to check the fungicidal resistance/sensitivity among six different isolates of $C$. gloeosporioides (Cg1-Cg7). Except for $\mathrm{Cg} 3$, which was mildly resistant to thiophanate-methyl, all isolates were highly susceptible to systemic fungicides. $\mathrm{Cg} 1, \mathrm{Cg} 3$, and $\mathrm{Cg} 6$ were highly vulnerable to mancozeb, while $\mathrm{Cg} 5$ and $\mathrm{Cg} 7$ were resistant, and $\mathrm{Cg} 2$ and $\mathrm{Cg} 4$ were highly resistant.

Generally, the systematic use of chemical fungicides for plant pathogen control has developed many related problems, including disease tolerance, human health damage, amassed toxic substances in plants and environmental pollution worldwide (Dubey et al., 2008). Using these substances creates awareness of potential risks to health and ecological consequences. Researchers have recently been interested in natural plant extracts due to their volatile nature, flavour, antioxidant, and antimicrobial effects (Dong et al., 2020; Topa et al., 2020). Plant secondary metabolism is responsible for producing alkaloids, terpenoids, flavonoids, polyphenols and phenols (Gulcin et al., 2004; Abad et al., 2007). These secondary metabolites/phytochemicals are reported as potent free radical scavengers and have significantly reduced the risk of diseases associated with oxidative stress (Wang et al., 2011; Wootton-Beard and Ryan, 2011). Many kinds of research are now focused on natural antioxidants as an alternative to synthetic additives in food and medicine. Hence, the alternative approach is to apply largely systematic, simply biological and non-phytotoxic botanical fungicides into the environment (Hanif et al., 2017; Munawwar et al., 2018; Bashir et al., 2019). There are vital records of rich antifungal components in the Euphorbiaceae family (Perea and Patterson, 2002; Silva et al.,2008; Khan et al., 2018).

Euphorbia tirucalli L. is a Euphorbiaceous plant commonly known as pencil tree, native to tropical regions with a pencil-like appearance. The white toxic latex secreted by this plant may contribute to its medicinal properties and low herbivore stress. The plant extract contains enormous amounts of sterols, terpenes and isolated substances, i.e. alfaeuforbol, taraxa, alcohol eufol, and tirucallol (Gupta et al., 2012). It was proposed from earlier literature that E. tirucalli possesses rich antimicrobic and pesticidal characteristics (Tiwari and Singh, 2006; Mwine and Van Damme, 2010; Jahanet al., 2011). Literature also supports that E. tirucalli extracts have an excellent antioxidant capacity and antimicrobial activity (Araujo et al., 2014). The latest interest is biologically sustainable antifungal compounds encouraged this research to study the antifungal efficacy of $E$. tirucalli against phytopathogenic fungal strain $C$. gloeosporioides. 


\section{Materials and methods}

\section{Collection of experimental material}

The whole plant of E. tirucalli had been collected from Canal Bank area Lahore, Pakistan. Before sterilizing, the products were washed thoroughly with tap water and treated with a sterilized distilled water solution containing one per cent sodium hypochlorite. Under sunlight, the plant materials were dried and ground to fine powder by an electrical blender and kept in zipper bags. The target fungus $C$. gloeosporioides was isolated from unhealthy mango inflorescence. The pathogen was identified using cultural, morphological, and conidial mechanisms such as colony colour, scale, and form. Mango fruit has previously been shown to have similar characteristics (Phoulivong et al., 2010; Wei et al., 2017). Sub-cultures were prepared and upheld on two per cent Malt Extract Agar (MEA) and maintained at $4{ }^{\circ} \mathrm{C}$ in the fridge.

\section{In vitro bioassays}

Assessment of test plant E. tirucalli in vitro was performed against target fungus (Hanif et al., 2017). Sun-dried fine grounded materials $(50 \mathrm{~g})$ of E. tirucalli were subjected to successive extraction with methanol $(150 \mathrm{~mL})$ and left for three days at $25^{\circ} \mathrm{C}$. Filtration through sterile muslin cloth was done, and the extract was concentrated using an electric oven at $40{ }^{\circ} \mathrm{C}$. Extract production was $5.5 \mathrm{~g}$ and then reconstituted with $27.5(\mathrm{~mL})$ of sterilized distilled water to produce $20 \%$ of the solution in stocks. Different concentrations of E. tirucalli plant methanolic extract $1.0 \%, 1.5 \%, 2.0 \%, 2.5 \%$ and $3.0 \%$ v/v were prepared. Malt Extract (2\%) medium, autoclaved in experimental flasks by adding ME $(0.6 \mathrm{~g})$ with $30 \mathrm{~mL}$ distilled water. Mixing of $1.5,2.25,3.0,3.75$ and $4.5 \mathrm{~mL}$ of stock solutions with 28.5, 27.75, 27 , 26.25, 25.5 (mL) $\mathrm{DH}_{2} \mathrm{O}$ in the medium was supplemented to make it up to $30 \mathrm{~mL}$. No plant extract was added to the control flasks. To avoid bacterial contamination standard antibiotic as Amoxicillin $\left(50 \mathrm{mg} \mathrm{mL}^{-1}\right)$ was added to each concentration. Each concentration was replicated thrice. C. gloeosporioides new discs were tipped in each flask for inoculation and left for incubation for seven days at $25{ }^{\circ} \mathrm{C}$. The fungal growth was checked using filter paper (Whatman No. 1); after a week, dried the filtrate in an electronic oven, and weight was measured. Inhibition (\%) was recorded by the given formula method:

$$
\text { Growthinhibition }(\%)=\frac{\text { Growthincontrol-Growthintreatment }}{\text { Growthincontrol }} \times 100
$$

\section{Quantitative analysis for free radical scavenging capability}

Methanolic plant extract of E. tirucalli was analyzed using DPPH (1, 1-diphenyl-2picrylhydrazyl) for its free radical scavenging capacity (Alam et al., 2008). Solution of DPPH $0.05 \% \mathrm{w} / \mathrm{v}$ was made in methanol $(95 \%)$. The plant extract $(0.4 \mathrm{~g})$ was mixed with $10 \mathrm{~mL}$ methanol for $4 \%$ standard solution. $2 \mathrm{~mL}$ of $0.05 \mathrm{mM}$ fresh DPPH solution was added in sterilized test tubes. The stock solution of E. tirucalli by serial dilutions $(200 \mu \mathrm{L}$ to $1500 \mu \mathrm{L})$ was mixed in each test tube to make it up to $4 \mathrm{~mL}$. After half an hour, the absorbance was recorded using UV - visible spectrophotometer (BMS UV2600) at $517 \mathrm{~nm}$. The reference standard was methanol, and control was made by adding the same volume of DPPH without plant extract. 95\% methanol was served as blank. By the given equation percentage scavenging activity of DPPH was measured: 
The inhibition curve was plotted and depicted as $\%$ of mean inhibition \pm standard deviation.

\section{Solvent partitioning bioassay}

Dried plant material (ground) was drenched in methanol $(200 \mathrm{~mL})$ for two days for solvent partitioning bioassay using organic solvents. After evaporation, the methanolic gummy mass ( $9 \mathrm{~g}$ ) was apportioned at ambient temperature with $n$-butanol, ethyl acetate, chloroform and $n$-hexane via a separating funnel (Sherazi et al., 2016). These four separated organic fractions have been tested against $C$. gloeosporioides in vitro. Fungal inoculums were made using saline solution, and each organic fraction consumed two concentrations, i.e. $0.5 \%$ and $1 \%$. The experiment was done by adding 0.75 , and $1.5 \mathrm{~mL}$ of all crude organic fractions into 2\% MEA medium and 29.25 and $28.5 \mathrm{~mL}$ distilled water making final volume upto $30 \mathrm{~mL}$. Thiophenate methyl (Benzimidazole) was used as a positive control. The experiment was replicated thrice, and $5 \mathrm{~mm}$ fungal mycelia discs were added in each replicate. The flasks were incubated over seven days at ambient temperature, and the drop in test fungal biomass had been measured using a formula:

$$
\text { Growthinhibition }(\%)=\frac{\text { Growthincontrol-Growthintreatment }}{\text { Growthincontrol }} \times 100
$$

\section{GC-MS (gas chromatography-mass spectrometric) investigation}

Bioactive phytochemicals of chloroform fraction of E. tirucalli methanolic plant extract were identified through GC-MS analysis. Hewlett Packard series 5890 Gas Chromatograph with Mass Selective Indicator 5973N was selected for the examination. The gas chromatography (GC) was interfaced to a mass spectrometer (MS) equipped with an Elite$5 \mathrm{MS}(95 \%$ dimethyl poly saline $/ 5 \%$ diphenyl) fused capillary column $(30 \times 0.25 \mu \mathrm{m}$ ID $\times$ $0.25 \mu \mathrm{m} \mathrm{Df}$ ). Electron impact mode at $70 \mathrm{Ev}$ was used for ionization in the GC-MS analysis. The initial oven temperature was $50^{\circ} \mathrm{C}$ for $2 \mathrm{~min}$, increased at $20^{\circ} \mathrm{C} / \mathrm{min}$ to $280^{\circ} \mathrm{C}$, and held for $10 \mathrm{~min}$. The injection was completed in a split-less manner with injection port temperature retained at $250{ }^{\circ} \mathrm{C}$. Data acquisition was accompanied in the MS scan mode (range 40-650 m/z). The comparative percentage area of every constituent was deliberated by comparing it to the entire range (Yusoff et al., 2017).

\section{Statistical analysis}

Data obtained in this study were statistically evaluated using variance (ANOVA) analysis to determine variability among groups by Statistix 8.1 software at a significance level of $\mathrm{P} \leq 0.05$.

\section{Results}

\section{Antifungal activity of methanolic extract of E. tirucalli}

All the tested concentrations of methanolic extract of E. tirucalli significantly suppressed the in vitro growth of $C$. gloeosporioides. However, out of five concentrations, two conc. $2.5 \%$ and $3 \%$ showed a maximum decline in the test fungal 
biomass, i.e. $64 \%$ and $77 \%$. Whereas $46 \%$ retardation was observed in $2 \%$ concentration as compared to control treatment. The most nominal growth was shown by $1.5 \%$ and $1 \%$ concentration with $32 \%$ and $23 \%$ retardation in the test fungus biomass (Fig. 1).

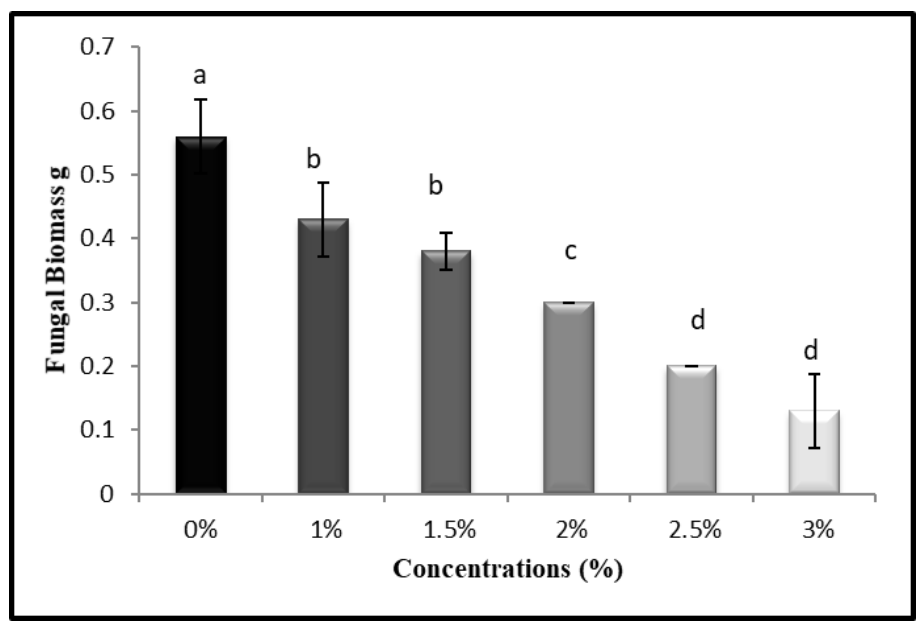

Figure 1. In vitro results of methanol extract of E. tirucalli against test fungus $C$. gloeosporioides. The straight bars appear as the standard error of means of three replicates determined by LSD $(P=0.05)$. Lowercase letters show insignificant variations checked by the LSD test

\section{Phytochemical analysis}

Phytochemical analysis of E. tirucalli revealed various bioactive compounds in test plants, i.e. alkaloids, saponins, terpenoids, flavonoids, and tannins. However, glycosides, phlobatannins and coumarins were absent (Table 1).

Table 1. Phytochemical screening of Euphorbia tirucalli

\begin{tabular}{c|c}
\hline Groups & Status* $^{*}$ \\
\hline Glycosides & - \\
Tannins & + \\
Flavonoids & + \\
Saponins & + \\
Terpenoids & + \\
Alkaloids & + \\
Phlobatannins & - \\
Coumarins & - \\
\hline
\end{tabular}

$*(+)$ means presence $(-)$ means an absence

\section{Antioxidant assay}

E. tirucalli antioxidant activity was measured through 1, 1-diphenyl-2-picryl-hydrazyl (DPPH) free radical scavenging assay. The outcomes of this experiment showed that the extract concentrations at all doses significantly exhibited high absorbance than control. At $200 \mu \mathrm{L}$ concentration of methanol extract revealed $81 \%$ radical scavenging activity. 
Figure 2 depicted the scavenging activity of E. tirucalli methanolic extract. The action was enhanced by increasing the sample extract concentration. The $\mathrm{IC}_{50}$ value for the test sample was recorded as 0.3801 using Graph Pad Prism 8.



Figure 2. DPPH radical scavenging activity of the methanol extract of E. tirucalli. Data were represented as \% of Mean inhibition $\pm S D$ of the experiment at the significance level $(P=0.05)$

\section{Antifungal activity (In-vitro) of extracted organic fractions of E. tirucalli}

The test plant methanol extract was apportioned with many organic solvents, namely ethyl acetate, chloroform, $n$-hexane and $n$-butanol. The in vitro activities of these fractions were tested. Significant retardation of $90 \%$ and $95 \%$ was exhibited by two concentrations $(0.5 \%$ and $1 \%)$ of chloroform extract of E. tirucalli after seven days of the incubation period (Fig. 3). While $0.5 \%$ and $1 \% n$-hexane concentration caused $80 \%$ inhibition in the test fungus biomass, ethyl acetate gave $40 \%$ and $50 \%$ reduction and the minor fungal growth reduction was recorded in $n$-butanol fraction, i.e. $36 \%$ and $54 \%$, respectively. In addition, positive control, i.e. thiophenate methyl (Benzimidazole), was also checked against C. gloeosporioides, and inhibition was recorded as $44 \%$ and $46 \%$.

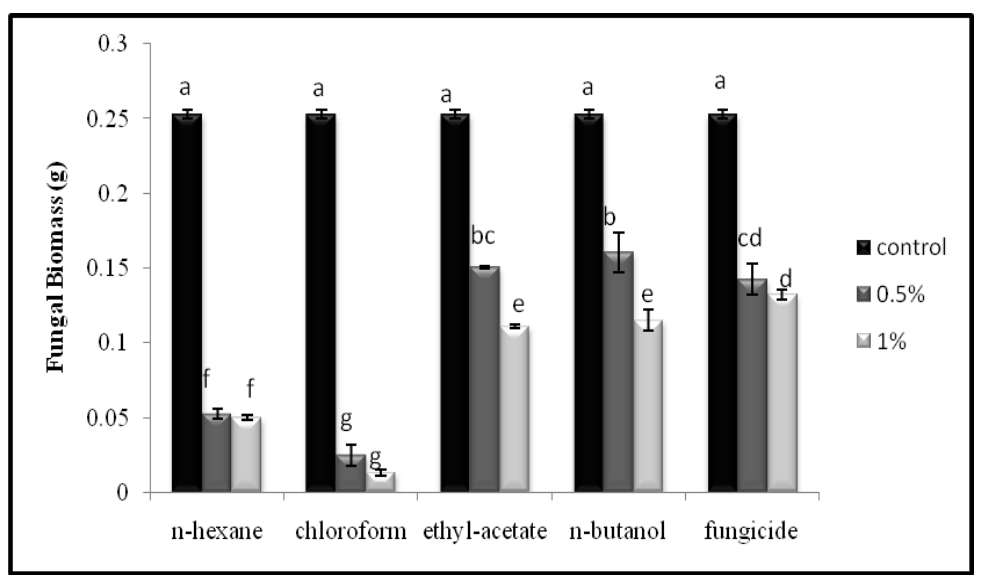

Figure 3. In vitro results of various organic solvent extracts of E. tirucalli against $C$. gloeosporioides. The standard error represented by straight lines. Lowercase letters show significant variations checked by $L S D(P=0.05)$ 


\section{GC-MS analysis of chloroform extract of E. tirucalli}

The present study has identified eleven compounds in the chloroform extract of $E$. tirucalli by GC-MS analysis. The peak report of the complete ion chromatogram has the specifics of peak number, retention time (RT), the name of the compound, molecular formula, molecular weight (MW) and area percentage as presented in Table 2. In addition, the disintegration patterns of the peak were characterized and likened to the mass spectra of the constituents with NIST libraries. A chromatogram with the peaks of the test constituents regarding retention time is shown in Figure 4. The compounds $n$ hexadecanoic acid with RT 18.676 has peak area $40.446 \%, 9$, 12-octadecadienoic acid (Z, Z) - with RT 20.948 has peak area $22.370 \%$, dodecanoic acid with RT 14.418 has peak area $10.258 \%$, tetradecanoic acid with RT 16.662 with peak area $7.491 \%$ and phytol with RT 19.908 has peak area $7.359 \%$ were recognized as main antifungal constituents. Most active compounds have an identical name or synonym name, which is essential for searching their function and application.

Table 2. Phytoconstituents found in the chloroform extract of E. tirucalli L. by GC-MS

\begin{tabular}{c|c|c|c|c|c}
\hline Sr. No & RT (Min) & Constituents & $\begin{array}{c}\text { Molecular } \\
\text { formula }\end{array}$ & $\begin{array}{c}\text { Molecular } \\
\text { weight }\end{array}$ & $\begin{array}{c}\text { Peak area } \\
(\%)\end{array}$ \\
\hline 1 & 14.418 & Dodecanoic acid & $\mathrm{C}_{12} \mathrm{H}_{24} \mathrm{O}_{2}$ & 200.317 & 10.258 \\
\hline 2 & 15.965 & 10-heneicosene (c,t) & $\mathrm{C}_{21} \mathrm{H}_{44}$ & 296.58 & 1.938 \\
\hline 3 & 16.662 & Tetradecanoic acid & $\mathrm{C}_{14} \mathrm{H}_{28} \mathrm{O}_{2}$ & 228.37 & 7.491 \\
\hline 4 & 17.138 & 2-pentadecanone,6,10,14-trimethyl- & $\mathrm{C}_{18} \mathrm{H}_{36} \mathrm{O}$ & 268.5 & 1.654 \\
\hline 5 & 17.688 & Pentadecanoic acid & $\mathrm{C}_{15} \mathrm{H}_{30} \mathrm{O}_{2}$ & 242.3975 & 1.509 \\
\hline 6 & 18.676 & $n$-hexadecanoic acid & $\mathrm{C}_{16} \mathrm{H}_{32} \mathrm{O}_{2}$ & 256.430 & 40.446 \\
\hline 7 & 19.159 & $\begin{array}{c}9,10 \text {-dimethyltricyclo } \\
{[4.2 .1 .1(2,5)] \text { decane-9,10-diol }}\end{array}$ & $\mathrm{C}_{12} \mathrm{H}_{20} \mathrm{O}_{2}$ & 196.29 & 2.717 \\
\hline 8 & 19.908 & Phytol & $\mathrm{C}_{20} \mathrm{H}_{40} \mathrm{O}$ & 296.539 & 7.359 \\
\hline 9 & 20.948 & 9,12 -octadecadienoic acid(Z,Z)- & $\mathrm{C}_{18} \mathrm{H}_{32} \mathrm{O}_{2}$ & 280.455 & 22.370 \\
\hline 10 & 24.852 & Scopolamine & $\mathrm{C}_{17} \mathrm{H}_{21} \mathrm{NO}_{4}$ & 303.353 & 4.258 \\
\hline 11 & 24.85 & $\begin{array}{c}\text { Methoxyaceticacid,2- } \\
\text { tetradecylester }\end{array}$ & $\mathrm{C}_{17} \mathrm{H}_{34} \mathrm{O}_{3}$ & 286.4 & 4.258 \\
\hline
\end{tabular}

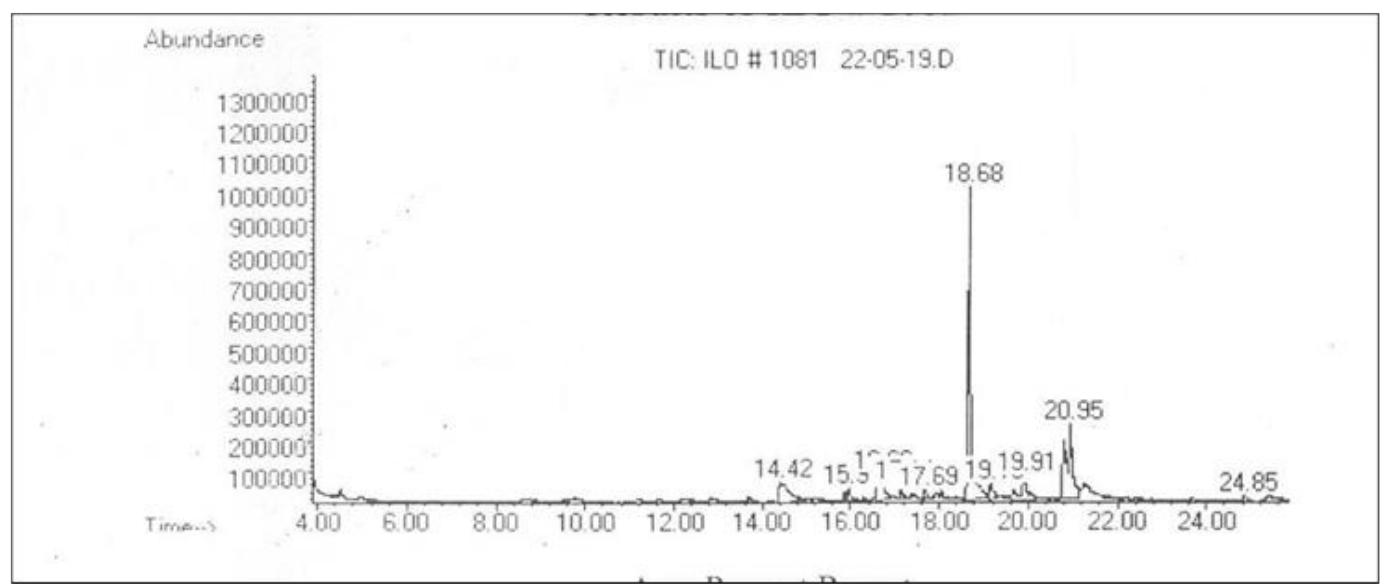

Figure 4. The chromatogram of GC-MS of E. tirucalli chloroform extract 


\section{Discussion}

Mango is one of the most valuable fruits in tropical and subtropical regions globally, both for domestic and foreign consumption (Khan et al., 2015). Asia dominates the global mango industry with 74.3 per cent of demand, led by America, Africa, and Oceania (Lawson et al., 2019). It is commonly known as "King of the Fruits," produced in around 90 countries around the globe as a reputable evolving tropical trade crop (Alam and Khan, 2001; Tahir et al., 2012). However, mangoes suffer a significant economic loss due to post-harvest decay caused by C. gloeosporioides (Konsue et al., 2020). Consumption of synthetic fungicides provides the initial protection for managing post-harvest fungal decay of fruits. To control and lessen chemical preservatives, natural plant sources have been utilized. Many indigenous plant extracts have been identified and reported as antifungal agents against $C$. gloeosporioides. Hence, the present investigation was done to check the antifungal extent of E. tirucalli for controlling of anthracnose disease of mango. All the tested concentrations (1-3\%) retarded the biomass of the test fungus. Significant reduction in the test fungal biomass was observed in $2.5 \%$ and $3 \%$ concentration, i.e. $64 \%$ and $77 \%$. Other applications of methanolic extract of the test plant also inhibited the fungal mycelium. Previous reports have shown that in vitro bioassay of $E$. hirta methanol extract caused a significant decrease in the colony diameter of $C$. gloeosporioides (Khan et al., 2018). Earlier Parekh et al. (2005) also described that methanol and aqueous extracts of E. hirta and $E$. tirucalli showed significant antibacterial exploitation. Upadhyay et al. (2010) reported that E. tirucalli methanolic leaf extract exhibited intense antifungal activity against Aspergillus fumigatus, A. flavus and Fusarium oxysporum.

Phytochemical analysis of E. tirucalli exhibited various bioactive compounds like alkaloids, terpenoids, saponins, flavonoids, and tannins. Literature supports the current work as E. tirucalli contains potential phytochemical constituents that showed antifungal and antimicrobial activities (Jyothiet al., 2008; Avelar et al., 2011; Inbathamizh and Padmini, 2012), but no report is available on their activity against $C$. gloeosporioides. These phytochemicals or bioactive compounds also implicate the antioxidant activity of plants. E. tirucalli antioxidant activity was measured through 1, 1-diphenyl-2-picryl-hydrazyl (DPPH) free radical scavenging assay. Outcomes of this experiment showed that the extract concentrations at all doses exhibited high absorbance than control. For example, at $200 \mu \mathrm{L}$ concentration, methanol extract revealed $81 \%$ radical scavenging activity. Previously Jyothi et al. (2008) ascertained that aqueous extract of E. tirucalli at $100 \mu \mathrm{g} \mathrm{mL}-1$ concentration showed more significant hydroxyl radical scavenging activity. The test is based on the capacity of a steady free radical, 1, 1-diphenyl-2-picryl-hydrazyl (DPPH), to decolourize in antioxidants presence. Furthermore, the radical scavenging activity of DPPH has been revealed to be directly linked with the total phenolic content found in the extract as proposed by various earlier reports (Saeed et al., 2012; Middha et al., 2013).

Methanolic extract of test plant was partitioned with different organic solvents viz. ethyl acetate, chloroform, $n$-hexane and $n$-butanol. Results showed the highest activity up to $90 \%$ - $95 \%$ by chloroform fraction and fungicide against targeted fungus. Literature researched within in vitro appraisal of chloroform, petroleum ether, acetone, hexane and methanol stem extracts of E. tirucalli and its fungicidal effects have been established against Aspergillus niger, A. fumigatus and Candida albicans. The study's outcome showed that the E. tirucalli acetone extracts were effective against the test organisms (Prasad et al., 2011). 
GC-MS investigation of the chloroform fraction of E. tirucalli was used to identify the bioactive compounds. Over-all eleven compounds were identified (Table 2), and among them, the major constituents are $n$-hexadecanoic acid $(40.446 \%), 9,12-$ octadecadienoic acid $(\mathrm{Z}, \mathrm{Z})-(22.370 \%)$, dodecanoic acid $(10.258 \%)$, tetradecanoic acid $(7.491 \%)$ and phytol (7.359\%). $n$-hexadecanoic acid (palmitic acid) recognized in the present study was observed as the largest constituent of fatty acids from Euphorbia species according to Ertas et al. (2015), similar to the results of our study. According to literature, fatty acids exhibit antifungal and antibacterial activity (Dilikaet al., 2000; McGraw et al., 2002). The second major compound found in E. tirucalli is 9, 12octadecadienoic acid $(\mathrm{Z}, \mathrm{Z})$ - commonly known as linoleic acid is an unsaturated fatty acid. This compound has been proven to inhibit the development of the phytopathogenic fungi Crinipellis perniciosa, Pyrenophora avenae, Rhizoctonia solani and Pythium ultimum (Walters et al., 2004). Dodecanoic acid and dodecyclic acid are other names for lauric acid, commonly found in animal and plant oils and fats, especially palm kernel oil and coconut oil identified in current research (Tangwatcharin et al., 2012). Previously, Yenjit et al. (2010) reported that in vitro tests of Areca catechu L. revealed three triterpenes, and one fatty acid, lauric acid, could inhibit $C$. gloeosporioides mycelial development. Tetradecanoic (myristic acid) is also a common natural fatty acid, and literature search has also proved that palmitic and myristic acids exhibited bioactivity against moulds (Altieri et al., 2009). In addition, 3,7,11,15-tetramethyl-2-hexadecen-1ol a (phytol) is an acyclic diterpene alcohol. Radulovicet al. (2006) tested phytol against a panel of microorganisms, and this compound proved to exhibit strong antimicrobial properties. Previous studies have shown that all eleven compounds exhibited antifungal activities, as presented in Table 3.

Table 3. List of compounds found in the chloroform extract of E. tirucalli L. and its antifungal activity reported previously

\begin{tabular}{|c|c|c|c|}
\hline No & Name of compound/common name & Compound nature & Antifungal activity (references) \\
\hline 1 & Dodecanoic acid/Lauric acid & Saturated fatty acid & $\begin{array}{c}\text { Inhibit spore germination of } \\
\text { Aspergillus niger (Rihakova et al., } \\
2001 \text { ) }\end{array}$ \\
\hline 2 & 10-heneicosene $(\mathrm{c}, \mathrm{t}) /$ Heneicosane & Saturated hydrocarbon & $\begin{array}{l}\text { Exhibit antifungal activity on the } \\
\text { growth Penicilliumsp, } C \text {. } \\
\text { albicans, A. glaucus and T. viride } \\
\text { (Mihailovicet al., 2011) }\end{array}$ \\
\hline 3 & Tetradecanoic acid/Myristic acid & Saturated fatty acid & $\begin{array}{l}\text { Exert bioactivity against moulds } \\
\text { (Altieri et al., 2009) }\end{array}$ \\
\hline 4 & 2-pentadecanone,6,10,14-trimethyl-/Phytone & Sesquiterpenoids & $\begin{array}{l}\text { Exhibit antibacterial and } \\
\text { antifungal properties (Yoo et al., } \\
\text { 2008; Seidel et al., 2004) }\end{array}$ \\
\hline 5 & Pentadecanoic acid & Saturated fatty acid & $\begin{array}{l}\text { Antibacterial and antifungal } \\
\text { activity of Excoecaria agallocha } \\
\text { (Agoramoorthyet al., 2007) }\end{array}$ \\
\hline 6 & n-hexadecanoic acid/Palmitic acid & Saturated fatty acid & $\begin{array}{c}\text { Antifungal activity of palmitic } \\
\text { acid against Candida spp } \\
\text { (Belarmino de Souza et al., 2015) }\end{array}$ \\
\hline 7 & 9,10-dimethyltricyclo $[4 \cdot 2 \cdot 1 \cdot 1(2,5)]$ decane-9,10-diol & Alcohol & $\begin{array}{c}\text { Showed antifungal activity against } \\
\text { Macrophomoina phaseolina } \\
\text { (Javaid et al., 2017) }\end{array}$ \\
\hline 8 & 3,7,11,15-tetramethyl-2-hexadecen-1-ol/Phytol & Diterpene alcohol & $\begin{array}{c}\text { Antimicrobial activity of } \\
\text { Equisetum arvense L. against } \\
\text { Aspergillus niger and Candida } \\
\text { albicans (Radulovicet al., 2006) }\end{array}$ \\
\hline
\end{tabular}




\begin{tabular}{c|c|c|c}
\hline 9 & 9,12 -octadecadienoic acid(Z,Z)-/Linoleic acid & Unsaturated fatty acid & $\begin{array}{c}\text { Exhibit antifungal activity against } \\
\text { Crinipellis perniciosa, } \\
\text { Rhizoctonia solani, Pyrenophora } \\
\text { avenae and Pythium ultimum } \\
\text { (Walters et al., 2004) }\end{array}$ \\
\hline 10 & Hyoscine/Scopolamine & Alkaloid & $\begin{array}{c}\text { The fungistatic activity of } \\
\text { hyoscyamine and scopolamine } \\
\text { against Magnaporthe oryzae } \text { and } \\
\text { Rhizoctonia solani (Abdel- } \\
\text { Motaalet al.,2010) }\end{array}$ \\
\hline 11 & Methoxyaceticacid,2-tetradecylester & Fatty acid & $\begin{array}{c}\text { Efficacy of Volatile organic } \\
\text { compounds in suppression of } \\
\text { Verticillium wilt of cotton (Zhang } \\
\text { et al.,2015) }\end{array}$ \\
\hline
\end{tabular}

\section{Conclusion}

This study has demonstrated that all compounds identified from Euphorbia tirucalli have exhibited significant antifungal potential against the target fungus. Thus, further investigations of the active compounds present in the test plant are essential to establish E. tirucalli as an antifungal plant against $C$. gloeosporioides. The plant extract also showed significant antioxidant properties, indicative of its potential as a source. $E$. tirucalli can be used to make a variety of modern bio fungicides that can be used to combat various phytopathogens, including mango anthracnose.

Acknowledgements. The authors are thankful to Botany Department, Lahore College for Women University, Lahore, Pakistan, and its support in this study is acknowledged.

\section{REFERENCES}

[1] Abad, M. J., Ansuategui, M., Bermejo, P. (2007): Active antifungal substances from natural sources. - Archive for Organic Chemistry 7: 116-145.

[2] Abdel-Motaal, F. F., El-Zayat, S. A., Kosaka, Y., El-Sayed, M. A., Kashima, R., Maeda, Y., Nassar, M. S. M. (2010): Antifungal activities of hyoscyamine and scopolamine against two major rice pathogens: Magna portheoryzae and Rhizoctonia solani. - Journal of General Plant Pathology 76(76): 102-111.

[3] Agoramoorthy, G., Chandrasekaran, M., Venkatesalu., Hsu, M. J. (2007): Antibacterial and antifungal activities of fatty acid methyl esters of the blind-your-eye mangrove from India. - Brazilian Journal of Microbiology 38(4).

[4] Alam, S. M., Khan, M. A. (2001): Mango - an important fruit of Pakistan. - Industry and Economy.

[5] Alam, M., Ghani, A., Subhan, N., Rahman, M., Haque, M., Majumder, M. (2008): Antioxidant and membrane stabilizing properties of the flowering tops of Anthocephalus cadamba. - Natural Product Communications 3(65): 7.

[6] Altieri, C., Bevilacqua, A., Cardillo, D., Sinigagalia, M. (2009): Antifungal activity of fatty acids and their monoglycerides against Fusarium spp in a laboratory medium. International Journal of Food Science and Technology 44(2): 242-245.

[7] Araujo, K. M., Lima, A. D., Silva, J. N., Rodrigues, L. L., Amorim, A. G. N., Quelemes, P. V., Santos, R. C., Rocha, J. A., Andrades, E. O., Leite, J. S. A., Mancini-Filho, J., Trindade, R. A. (2014): Identification of phenolic compounds and evaluation of antioxidant and antimicrobial properties of Euphorbia tirucalli L. - Antioxidants 3: 159175 . 
[8] Avelar, B. A., Lélis, F. J. N., Avelar, R. S., Weber, M., Souza-Fagundes, E. M., Lopes, M. T. P. (2011): The crude latex of Euphorbia tirucalli modulates the cytokine response of leukocytes, especially $\mathrm{CD}^{+} \mathrm{T}$ lymphocytes. - Revista Brasileria de Farmacognosia 21(4): 662-667.

[9] Bashir, S., Jabeen, K., Iqbal, S., Javed, S., Naeem, A. (2019): Lantana camara: phytochemical analysis and antifungal prospective. - Plantadaninha 37: 1-7.

[10] Belarmino de Souza, T., Bretas, A. C. O., Alves, R. J., Magalhaes, T. F. F., Stoianoff, M. A. R. (2015): Synthesis and antifungal activity of Palmitic acid-based neoglycolipds related to Papulacandin D. - Artigo 38(10): 1282-1288.

[11] Dean, R., Van, Kan, J. A., Pretorius, Z. A., Hammond-Kosack, K. E., Pietro, A. D. I., Spanu, P. D., Rudd, J. J., Dickman, M., Kahmann, R., Ellis, J., Foster, G. D. (2012): The Top 10 fungal pathogens in molecular plant pathology. - Molecular Plant Pathology 13: 414-430.

[12] Dessalegn, Y., Ayalew, A., Woldetsadik, K. (2013): Integrating plant defense inducing chemical, inorganic salt and hot water treatments for the management of post-harvest mango anthracnose. - Post-harvest Biology and Technology 85: 83-88.

[13] Dilika, F., Brenner, P. D., Meyer, J. J. M. (2000): Antibacterial activity of linoleic and oleic acids isolated from Helichrysum pedunculatum: a plant used during circumcision rites. - Fitoterapia 71: 450-452.

[14] Dirou, J., Stovold, G. (2005): Fungicide management program to control mango anthracnose. - Prime Fact 19.

[15] Dong, J., Zhang, L., Liu, Y., Xu, N., Zhou, S., Yang, Q., Yang, Y., Ai, X. (2020): Thymol protects channel catfish from Aeromonas hydrophila Infection by inhibiting aerolysin expression and biofilm formation. - Microorganisms 8: 636.

[16] Dubey, N., Srivastava, B., Kumar, A. (2008): Current status of plant products as botanical pesticides in storage pest management. - Journal of Biopesticide 1(2): 182-186.

[17] Ertas, A., Yilmaz, M. A., Firat, M. (2015): Chemical profile by LC-MS/MS, GC/MS and antioxidant activities of the essential oils and crude extracts of two Euphorbia species. Natural Product Research 29: 529-534.

[18] Farr, D. F., Aime, M. C., Rossman, A. Y., Palm, M. E. (2006): Species of Colletotrichum on agavaceae. - Mycological Research 110: 1395-1408.

[19] Gulcin, I., Uguz, M. T., Oktay, M., Beydemir, S., Kufrevioglu, O. I. (2004): Evaluation of the antioxidant and antimicrobial activities of Clary Sage (Slavia sclarea L.). - Turkish Journal of Agriculture and Forestry 28: 25-33.

[20] Gupta, N., Vishnoi, G., Wal, A., Wal, P. (2012): Medicinal value of Euphorbia tirucalli. - Systematic Reviews in Pharmacy 4(1): 40.

[21] Hanif, S., Jabeen, K., Iqbal, S. (2017): Management of damping off disease by extracts of Albizia lebbeck (L.) Benth. - Bangladesh Journal of Botany 46(3): 1009-1014.

[22] Huang, C. Y., Kuo, C. H., Wu, C. H., Kuan, A. W., Guo, H. R., Lin, Y. H., Wang, P. K. (2018): Free radical scavenging, anti-inflammatory, and antibacterial activities of water and ethanol extracts prepared from compressional-puffing pretreated mango (Mangifera indica L.) peels. - Journal of Food Quality 1025387.

[23] Inbathamizh, L., Padmini, E. (2012): Gas chromatography-mass spectrometric analyses of methanol extract of Moringa oleifera flowers. - International Journal of AnalyticalBioScience 3(5): 1394-1397.

[24] Jahan, N., Khalil-Ur-Rehman., Ali, S., Bhatti, I. A. (2011): Antimicrobial potential of gemmo-modified extracts of Terminalia arjuna and Euphorbia tirucalli. - International Journal Agriculture and Biology 13(6): 1001-1005.

[25] Javaid, A., Qudsi, H., Shoaib, A. (2017): Bioassay guided fractionation of Senna occidentalis for identification of natural antifungal constituents against Macrophomina phaseolina. - Planta Daninha 35. https://doi.org/10.1590/S0100-83582017350100002. 
[26] Jyothi, T. M., Shankariah, M. M., Prabhu, K., Lakshminarasu, S., Srinivasa, G. M., Ramachandra, S. S. (2008): Hepatoprotective and antioxidant activity of Euphorbia tirucalli. - Iranian Journal of Pharmacology and Therapeutics 7(1): 25-30.

[27] Kenganal, M., Ranebennur, H., Byadgi, A. S. (2010): Management of anthracnose in mango. - University of Agricultural Sciences, Dharwad Karnataka. Online Edition of India's National Newspaper.

[28] Khan, A. S., Ali, S., Khan, I. A. (2015): Morphological and molecular characterization and evaluation of mango germplasm: an overview. - Scientia Horticulturae 194: 353-366.

[29] Khan, B., Jabeen, K., Iqbal, S. (2018): Fungistatic potential of Euphorbia hirta L. against the cause of anthracnose. - Romanian Biotechnological Letters 23(6): 1-10.

[30] Konsue, W., Dethoup, T., Limtong, S. (2020): Biological control of fruit rot and anthracnose of post-harvest mango by antagonistic yeasts from economic crops leaves. Microorganisms 8: 317.

[31] Kumar, A. S., Reddy, N. P. E., Reddy, K. H., Devi, M. C. (2007): Evaluation of fungicidal resistance among Colletotrichum gloeosporioides isolates causing mango anthracnose in agri export zone of Andhra Pradesh, India. - Plant Pathology Bulletin 16: 157-160.

[32] Lawson, T., Grantley, W. L., Asgar, A., Chiew, F. C. (2019): Characterization of Southeast Asia mangoes (Mangifera indica L) according to their physicochemical attributes. - Scientia Horticulturae 243: 189-196.

[33] Li, R. W., Leach, D. N., Myers, P., Leach, G. J., Lin, G. D., Brushett, D. J., Waterman, P. G. (2004): Anti-inflammatory activity, cytotoxicity and active compounds of Tinospora smilacina Benth. - Phytotherapy Research 18: 78-83.

[34] Mcgraw, L. J., Jager, A. K., Van Staden, J. (2002): Isolation of antibacterial fatty acids from Schotia brachypetala. - Fitoterapia 73: 431-433.

[35] Memon, N. A. (2016): Mango: Pakistan $4^{\text {th }}$ largest Producer in the World. - Pakistan Food Journal 24-26.

[36] Middha, S. K., Ushat., Pande, V. (2013): HPLC evaluation of phenolic profile, nutritive content, and antioxidant capacity of extracts obtained from Punica granatum fruit peel. Advances in Pharmacological Sciences. https://doi.org/10.1155/2013/296236.

[37] Mihailovic, V., Vukovic, N., Niciforovic, N., Solujic, S., Mladenovic, M., Maskovic, P., Stankovic, M. S. (2011): Studies on the antimicrobial activity and chemical composition of the essential oils and alcoholic extracts of Gentiana asclepiadea. - Journal of Medicinal Plants Research 5(7): 1164-1174.

[38] Munawwar, M., Jabeen, K., Iqbal, S. (2018): Biochar and compost antifungal activity against Botrytis Cinerea Pers. Ex. Fe. - Bangladesh Journal of Botany 47(1): 141-146.

[39] Mwine, J., Damme, P. V. (2010): Evaluation of selected pesticidal plant extracts against major cabbage insect pests in the field. - Tropentag: "World Food System - A Contribution from Europe," ETH Zurich, Switzerland.

[40] Pandey, A., Yadava, L. P., Manoharan, M., Chauhan, U. K., Pandey, B. K. (2012): Effectiveness of cultural parameters on the Growth and sporulation of Colletotrichum gloeosporioides causing anthracnose disease of Mango (Mangifera indica 1.). - Online Journal of Biological Sciences 12: 123-133.

[41] Parekh, J., Jadeja, S., Chanda, S. (2005): Efficacy of aqueous and methanol extracts of some medicinal plants for potential antibacterial activity. - Turkish Journal of Biology 29: 203-210.

[42] Perea, S., Patterson, T. F. (2002): Antifungal resistance in pathogenic fungi. - Clinical Infectious Diseases 35: 1073-1080.

[43] Phoulivong, S., Cai, L., Chen, H., McKenzie, E. H. C., Abdelsalam, K., Chukeatirote, E., Hyde, K. D. (2010): Colletotrichum gloeosporioides is not a common pathogen on tropical fruits. - Fungal Divers. 44: 33-43. 
[44] Prasad, S., Swapna, N. L., Prasad, M. (2011): Efficacy of Euphorbia tirucalli (L) towards microbicidal activity against human pathogens. - International Journal of Pharma and Bio Sciences 2: 12-18.

[45] Pscheidt, J. W., Ocamb., C. M. (2018): Pacific Northwest Plant Disease Management Handbook [online]. - Oregon State University, Corvallis, OR.

[46] Radulovic, N., Stojanovic, G., Palic, R. (2006): Composition and antimicrobial activity of Equisetum arvense L. essential oil. - Phytotherapy Research 20(1): 85-88.

[47] Rihakova, Z., Plockova, M., Filip, V., Smidrkal, J. (2001): Antifungal activity of lauric acid derivatives against Aspergillus niger. - European Food Research and Technology 213(6): 488-490.

[48] Saeed, N., Khan, M. R., Shabbir, M. (2012): Antioxidant activity, total phenolic and total flavonoid contents of whole plant extracts Torilis leptophylla L. - BMC Complementary and Alternative Medicine 12: 221.

[49] Sauco, V. G. (2017): Trends in world mango production and marketing. - Acta Horticulture 1183: 351-363.

[50] Schulze-Kaysers, N., Feuereisen, M. M., Schieber, A. (2015): Phenolic compounds in edible species of the Anacardiaceae family - a review. - RSC Advances 5: 73301-73314.

[51] Seidel, V., Taylor, P. W. (2004): In-vitro activity of extracts and constituents of Pelagonium against rapidly growing mycobacteria. - International Journal of Antimicrobial Agents 23: 613-619.

[52] Shah, K. A., Patel, M. B., Patel, R. J., Parmar, P. K. (2019): Mangi feraindica (Mango). Pharmacognosy Reviews 4: 42-48.

[53] Sherazi, A. Z., Jabeen, K., Iqbal, S., Yousaf, Z. (2016): Management of Ascochyta rabiei by Chenopodium album extracts. - Planta Daninha 34(4): 675-680.

[54] Silva, P. R., Rabelo, R. A. S., Terra, A. P. S., Teixeira, D. N. S. (2008): Susceptibility to antifungal agents among Cryptococcus neoformans varieties isolated from patients at a university hospital. - Revista da Sociedade Brasileirade Medicina Tropical 41: 158-162.

[55] Slavin, J. L., Lloyd, B. (2012): Health benefits of fruits and vegetables. - Advances in Nutrition 3: 506-516.

[56] Sundravadana, S., Alice, D., Kuttalam, S., Samiyappan, R. (2006): Control of mango anthracnose by Azoxystrobin. - Tunisian Journal of Plant Protection 1: 109-114.

[57] Tahir, W. A., Ahmad, M., Iftikhar, M. (2012): An analysis of the effectiveness of extension work conducted by public sector with special reference to mango in the southern Punjab, Pakistan. - Pakistan Journal of Agricultural Sciences 49: 229-232.

[58] Tangwatcharin, P., Khopaibool, P. (2012): Activity of virgin coconut oil, lauric acid or monolaurin in combination with lactic acid against Staphylococcus aureus. - Southeast Asian Journal of Tropical Medicine and Public Health 43(4): 969-985.

[59] Tiwari, S., Singh, A. (2006): Biochemical stress response in freshwater fish Channa punctatusinduced by aqueous extracts of Euphorbia tirucalli plant. - Chemosphere 64: $36-42$.

[60] Topa, S. H., Palombo, E. A., Kingshott, P., Blackall, L. L. (2020): Activity of cinnamaldehyde on quorum sensing and biofilm susceptibility to antibiotics in Pseudomonas aeruginosa. - Microorganisms 8: 455.

[61] Upadhyay, B., Singh, K. P., Kumar, A. (2010): Ethno-medicinal, phytochemical and antimicrobial studies of Euphorbia tirucalli L. - Journal of Phytology 2(4): 65-77.

[62] Walters, D., Raynor, L., Mitchell, A., Walker, R., Walker, K. (2004): Antifungal activity of four fatty acids against plant pathogenic fungi. - Mycopathologia 157: 87-90.

[63] Wang, S., Melnyk, J. P., Tsao, R., Marcone, M. F. (2011): How natural dietary antioxidant in fruits, vegetables and legumes promote a vascular health. - Food Research International 44: 14-22.

[64] Wei, Y., Pu, J., Zhang, H., Liu, Y., Zhou, F., Zhang, K., Liu, X. (2017): The laccase gene (LACl) is essential for Colletotrichum gloeosporioides development and virulence on 
mango leaves and fruits. - Physiological and Molecular Plant Pathology. DOI: 10.1016/j.pmpp.2017.03.005.

[65] Wootton-Beard, P. C., Ryan, L. (2011): Improving public health. The role of antioxidantrich fruit and vegetables beverages. - Food Research International 44: 3135-3148.

[66] Yenjit, P., Issavakraisila, M., Intana, W., Chantrapromma, K. (2010): Fungicidal activity of compounds extracted from the pericarp of Areca catechu against Colletotrichum gloeosporioides in vitro and in mango fruit - Postharvest Biology and Technology 55(2): 129-132.

[67] Yoo, Y. M., Nam, J. H., Kim, M. Y., Choi, J., Parz, H. J. (2008): Pectolinarin and pectolianarigenin of Cirsium setidens prevent the hepatic injury in rats caused by Dgalactosamine via an antioxidant mechanism. - Biological and Pharmaceutical Bulletin 31: 760-764.

[68] Yusoff, E., Ahmad, A., Mohamad, S., Muhammad, N. F. (2017): GC-MS analysis of some volatile constituents extracted from stem of Euphorbia tirucalli Linn. - Archives of Orofacial Sciences 12(1): 36-44.

[69] Zhang, Q., Yang, L., Zhang, J., Wu, M., Chen, W., Jiang, D., Li, G. (2015): Production of antifungal volatiles by non-pathogenic Fusarium oxysporum and its efficacy in suppression of Verticillium wilt of cotton. - Plant and Soil 392(1-2): 101-114. 